\title{
QUANTITATIVE ANALYSIS OF PROSTACYCLIN BY HIGH PERFORMANCE LIQUID CHROMATOGRAPHY
}

Prostacyclin (prostaglandin (PG) $\mathrm{I}_{2}$ ) was discovered by J. R. Vane and his co-workers in 1976 [ ${ }^{1}$ ]. It appeared to be the strongest inhibitor of platelet aggregation described so far [ $\left.{ }^{1}\right]$. Also, $\mathrm{PGI}_{2}$ was further characterized as a potent vasodilator and cytoprotector $\left[{ }^{1,2}\right]$. These properties make it an important candidate for therapeutic use. Unfortunately, $\mathrm{PGI}_{2}$ is chemically extremely unstable. In acid or neutral aqueous conditions, its cyclic enolether unit is hydrolyzed within a few minutes into 6 -keto-PGF $\mathrm{PG}_{1 \alpha}[1,3,4]$. Although under unhydrous conditions $\mathrm{PGI}_{2} \mathrm{Na}$-salt is stable in crystalline form, determination of the chemical purity of prostacyclin samples is obligatory for investigators studying the physiological activity of this compound.

The chemical unstability of $\mathrm{PGI}_{2}$ gives rise to serious problems in its analysis. In solving these problems, G. T. Hill suggested the use of high performance liquid chromatographic method on reverse phase columns $\left.{ }^{5}\right]$. M. A. Wynalda, F. N. Lincoln and F. A. Fitzpatrick found an excellent mobile phase for eluting $\mathrm{PGI}_{2} \mathrm{Na}$-salt and its impurities. It consists of acetonitrile and water buffered at $\mathrm{pH} 9.3$ with boric acid and sodium borate $\left[{ }^{6}\right]$. They used the external standard method that requires full-loop injections and regular peak shapes. The external standard method requires, before each series of sample analysis, injection of $\mathrm{PGI}_{2} \mathrm{Na}$-salt with high purity for comparison. This gives once more rise to some problems due to the unstability of $\mathrm{PGI}_{2} \mathrm{Na}$-salt. Besides, the precision of the method is low $\left.{ }^{6}\right]$. Such a situation suggests the need for the development of an internal standard method for analyzing $\mathrm{PGI}_{2}$ Na-salt.

Two methods were tested. In the first method one internal standard and specially purified $\mathrm{PGI}_{2} \mathrm{Na}$-salt are used for calibration and in the second one two internal standards plus technical grade $\mathrm{PGI}_{2}$ Na-salt are employed.

\section{Materials and methods}

Apparatus. A DuPont HPLC system N 8845 with a Rheodyne Model 7125 Syringe Loading Sample Injector (maximum sample size $50 \mu l$ ). A spectrophotometric detector was set at $205 \mathrm{~nm}$ and 0.64 AUFS. A recorder operated at $10 \mathrm{~cm} / \mathrm{h}$.

Reagents. Boric acid, sodium borate and sodium hydroxide (Reakhim, USSR) were used without purification. Acetonitrile (Reakhim) was redistilled. Bidistilled water was used. $\mathrm{PGI}_{2} \mathrm{Na}$-salt ( $99 \%$ by HPLC, mp. $164-166^{\circ}$ ) was prepared according to $\left[7^{7-10}\right]$ and crystallized twice from water-acetonitrile $(0.5: 15)$. 6-keto- $\mathrm{PGF}_{1 \alpha}$ methyl ester was prepared in different batches according to $\left.{ }^{7}\right]$. Ester moiety was hydrolyzed by a $1 \mathrm{~N} \cdot \mathrm{NaOH}$ solution in methanol. Biosynthetic $\mathrm{PGE}_{1}$ (mp. 114-116 ) 
used also as an internal standard was tested to be at least $99 \%$ pure by HPLC $\left[{ }^{11}\right]$.

Chromatographic conditions. Chromatography was performed at ambient temperature on a $4.0 \times 220 \mathrm{~mm}$ Zorbax ODS column or $4.6 \times 250 \mathrm{~mm}$ column prepacked with a Zorbax ODS. The columns were eluated with acetonitrile-water. $(85-87 \%$ of water, buffered at $\mathrm{pH} 9.3$ with $0.01 \mathrm{M}$ boric acid and $0.006 \mathrm{M}$ sodium borate) at a flow rate of $0.8-1.0 \mathrm{ml} / \mathrm{min}$.

Direct analysis with $\mathrm{PGE}_{1}$ as an internal standard. Method A. In order to obtain the calibration curve, 5 different quantities of pure $\mathrm{PGI}_{2}$ $\mathrm{Na}$-salt in the range of $1.0-3.5 \mathrm{mg}$ were weighed $\left(W_{I}\right)$ and the precise amounts $(1.0-3.5 \mathrm{mg})$ of $\mathrm{PGE}_{1}\left(W_{E}\right)$ were added; the samples were dissolved in $300 \mu \mathrm{l}$ of water buffered at $\mathrm{pH} 10.1$ with $0.013 \mathrm{M}$ sodium borate and $0.023 M$ sodium hydroxide at $4^{\circ}$. In each case, $5 \mu$ l of the sample was injected and the rest was kept at $4^{\circ}$ between reinjections. Each sample injection was performed twice.

Analyses with $\mathrm{PGE}_{1}$ and 6-keto- $\mathrm{PGF}_{1 \alpha}$ as internal standards. Method $\mathrm{B}$. In order to obtain the calibration curve, 11 different quantities of $\mathrm{PGI}_{2}$ $\mathrm{Na}$-salt in the range of $1.0-3.5 \mathrm{mg}$ were weighed and the precise amounts $(1.0-3.5 \mathrm{mg})$ of $\mathrm{PGE}_{1}\left(W_{E}\right)$ were added. An aqueous solution of 6-keto-PGF $\mathrm{P}_{1 \alpha}$ was prepared in a concentration of $10 \mathrm{mg} / \mathrm{ml}$, buffered at $\mathrm{pH} 10.1$ with $0.013 \mathrm{M}$ sodium borate and $0.023 \mathrm{M}$ sodium hydroxide and kept at $4^{\circ}$ before using. Thereupon, $8-100 \mu \mathrm{l}$ of the 6 -keto-PGF G $_{1 \alpha}$ solution (the weight of 6-keto-PGF $1 \alpha\left(W_{F}\right)$ ) was added to the weighed samples of $\mathrm{PGI}_{2} \mathrm{Na}$-salt. The same buffer was added till the total volume of the sample of $300 \mu \mathrm{l}$. In each case, $5 \mu \mathrm{l}$ of the sample was injected and the rest was kept at $4^{\circ}$ between reinjections. Each sample injection was performed twice. Subsequently, $\mathrm{PGI}_{2} \mathrm{Na}$-salt was converted into 6-keto- $\mathrm{PGF}_{1 \alpha}$ by acidifying the samples with acetic acid up to $\mathrm{pH} 5-6$. Then, $0.1 \mathrm{~N}$ sodium hydroxide was added at $4^{\circ}$ up to $\mathrm{pH} 8-9$ and $15 \mu \mathrm{l}$ of the sample was injected. The samples were stored and reinjected as described above.

Calculations. The peak areas were calculated by $«$ Height $\times$ Width at Half Height» technique [12].

Response factor of $\mathrm{PGI}_{2}$ Na-salt versus PGE

$$
f=\frac{A_{I} W_{E}}{A_{E} W_{I}}
$$

where $A_{I}$ and $A_{E}$ are the peak areas of $\mathrm{PGI}_{2} \mathrm{Na}$-salt and $\mathrm{PGE}_{1}, W_{I}$ and $W_{E}$ are their weights, respectively.

Corrected $\mathrm{PGE}_{1}$ peak area

$$
A_{E}^{c o r r}=A_{E}-A_{I} \times k
$$

where $k$ is the area fraction of interfering impurity in $\mathrm{PGI}_{2} \mathrm{Na}$-salt.

Formulas analogous to (1) and (2) may be used in calculations for 6-keto-PGF $\mathrm{PG}_{1 \alpha}$ when $\mathrm{PGI}_{2} \mathrm{Na}$-salt contains 6-keto-PGF $1 \alpha$.

$\mathrm{Real}$ weight of $\mathrm{PGI}_{2}$ Na-s alt (the difference in molecular masses of 6-keto-PGF $1 \alpha$ and $\mathrm{PGI}_{2}$ Na-salt is neglected)

$$
W_{I}^{r e a l}=\left(\frac{R_{A}^{\prime \prime}}{R_{A}^{\prime}}-1\right) W_{F}
$$

where $R_{A}^{\prime}$ and $R_{A}^{\prime \prime}$ are the ratios of peak areas of 6 -keto-PGF $1 \alpha$ to these of $\mathrm{PGE}_{1}$ before and after acidification, respectively, $W_{F}$ is the weight of 6-keto-PGF $1 \alpha$. 


\section{Results and discussion}

$\mathrm{PGI}_{2} \mathrm{Na}$-salt is synthesized from 5-iodo-PGI methyl ester according to the following scheme:

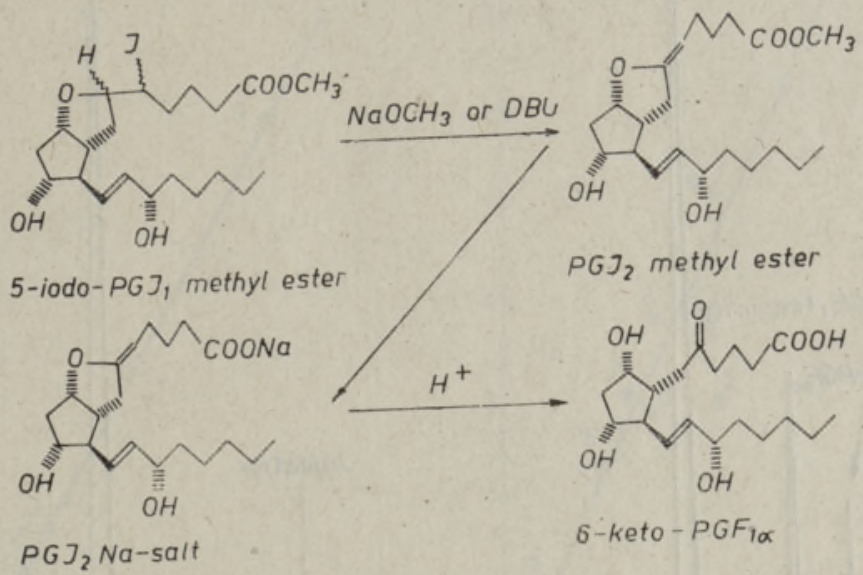

The main impurities of $\mathrm{PGI}_{2} \mathrm{Na}$-salt (technical grade) are 6-keto$\mathrm{PGF}_{1 \alpha}$, an unidentified compound in an amount of $1-3.5 \%$ of $\mathrm{PGI}_{2}$ $\mathrm{Na}$-salt and inorganic salts $(\mathrm{NaOH}, \mathrm{NaI})$.

The internal standard method requires that the standard should eluate near the peaks of interest and should be of high purity and chemically stable. We found that $\mathrm{PGE}_{1}$ meets these requirements. It has an acceptable retention time under the chromatographic conditions used. The capacity factor $k^{\prime}$, measured on a Zorbax ODS column for 6-keto- $\mathrm{PGF}_{1 \alpha}, \mathrm{PGE}_{1}$, and $\mathrm{PGI}_{2} \mathrm{Na}$-salt, was $0.9,3.4$ and 9.0, respectively (Fig. 1). The fact that $\mathrm{PGE}_{1}$ eluates between 6-keto- $\mathrm{PGF}_{1 \alpha}$ and $\mathrm{PGI}_{2}$ $\mathrm{Na}$-salt is also of importance. The purity of the crystalline $\mathrm{PGE}_{1}(99 \%$ by HPLC) meets the analytical requirements.

It is well known that under basic conditions $\mathrm{PGE}_{1}$ converts into $\mathrm{PGB}_{1}$ via. $\mathrm{PGA}_{1}\left[{ }^{13,14}\right]$. By examining UV-spectra of $\mathrm{PGE}_{1}$ at ambient temperature we found that at $\mathrm{pH} 9.3$ less than $1 \%$ of $\mathrm{PGE}_{1}$ is degradated into $\mathrm{PGA}_{1}\left(\lambda_{\max }=217 \mathrm{~nm} ; \varepsilon=10830\right)\left[{ }^{15}\right]$ during $1 \mathrm{~h}$. At $\mathrm{pH} 10.1$ $1.4 \%$ of $\mathrm{PGE}_{1}$ was converted into $\mathrm{PGA}_{1}$ in 30 min. The conversion of $\mathrm{PGA}_{1}$ into $\mathrm{PGB}_{1}\left(\lambda_{\max }=278 \mathrm{~nm} ; \varepsilon=26800\right)$ [ $\left.{ }^{16}\right]$ proceeds much slower. Only $0.7 \%$ of $\mathrm{PGE}_{1}$ can be converted into $\mathrm{PGB}_{1}$ in 18 hs at $\mathrm{pH} 10.1$. Also, by HPLC two injections from one sample under the above conditions were coincident with a precision of $1 \%$. No trace amounts of $\mathrm{PGA}_{1}$ or $\mathrm{PGB}_{1}$ were detected.

Calibration of $\mathrm{PGI}_{2} \mathrm{Na}$-salt versus $\mathrm{PGE}_{1}$ was performed by two different methods. In the first method (method A) the twice recrystallized $\mathrm{PGI}_{2}$ Na-salt (Fig. 2) was used. The real peak areas of the weighed amounts of $\mathrm{PGI}_{2} \mathrm{Na}$-salt and $\mathrm{PGE}_{1}$ were measured. An assumption was made that the response of the detector to $\mathrm{PGI}_{2} \mathrm{Na}$-salt and $\mathrm{PGE}_{1}$ is linear to their amount in the investigated region. From the calibration curve obtained (Fig. 3,a) the response factor $f_{A}$ of $\mathrm{PGI}_{2}$ Na-salt versus $\mathrm{PGE}_{1}$ on the UV-detector at $205 \mathrm{~nm}$ was calculated and found to be $3.65 \pm 0.15$ at a confidence level of $95 \%$.

By the second method (method $\mathrm{B}$ ), the peak areas of 6-keto-PGF $\mathrm{P}_{1 \alpha}$ $\left(A_{F}\right)$ and $\mathrm{PGI}_{2} \mathrm{Na}$-salt $\left(A_{I}\right)$ were measured and the peak area of $\mathrm{PGE}_{1}$ was calculated according to formula (2). For each sample the ratio of the peak areas of 6-keto-PGF $i \alpha$ to the peak area of $\mathrm{PGE}_{1}\left(R_{A}^{\prime}\right)$ was calculated, Analogously, these ratios $\left(R_{A}^{\prime \prime}\right)$ were determined after acid- 


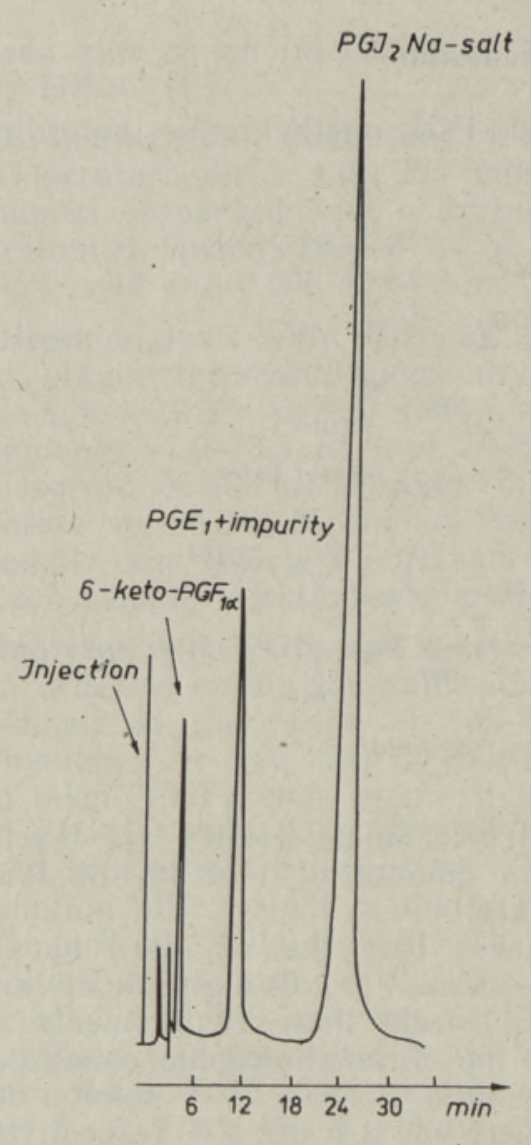

Fig. 1. Chromatogram of a mixture of 6-keto- $\mathrm{PGF}_{1 \alpha}$ and $\mathrm{PGE}_{1}$ and $\mathrm{PGI}_{2} \mathrm{Na}$-salt (technical grade) used for calibration in method B. Chromatography was performed on a Zorbax ODS $(4.6 \times 250 \mathrm{~mm})$ column using acetonitrile-water as - mobile phase $(13: 87, \mathrm{v} / \mathrm{v})$, buffered at $\mathrm{pH}$ 9.3 with $0.01 M$ boric acid and $0.006 \mathrm{M}$ sodium borate. The flow rate was 1.0 $\mathrm{ml} / \mathrm{min}$. The detector was set at $205 \mathrm{~nm}$ and 0.64 AUFS. The recorder operated at $10 \mathrm{~cm} / \mathrm{h}$.

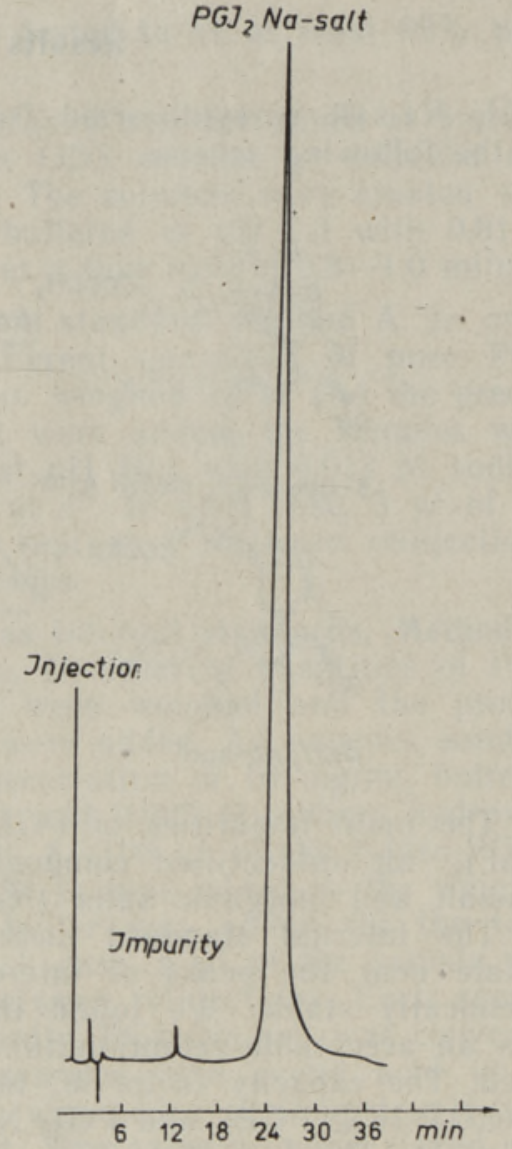

Fig. 2. Chromatogram of $\mathrm{PGI}_{2} \quad \mathrm{Na}$-salt (standard grade) used for calibration in method A. Chromatographic conditions are as in Fig. 1.

ifying the samples. From the increase in the peak areas ratio the amount of $\mathrm{PGI}_{2} \mathrm{Na}$-salt $\left(W_{I}\right)$ in the sample was calculated according to formula (3). By method $\mathrm{B}$ the response factor of $\mathrm{PGI}_{2} \mathrm{Na}$-salt versus $\operatorname{PGE}_{1}\left(f_{B}\right)$ was found to be $4.3 \pm 1.1$ at a confidence level of $95 \%$. The response factor of 6 -keto- $\mathrm{PGF}_{1 \alpha}$ versus $\mathrm{PGE}_{1}$ was found to be $0.68 \pm 0.20$ at a confidence level of $95 \%$.

As can be seen from Fig. 3, method A gives a calibration curve which is in accordance with experimental data. Method B, on the contrary, gives a calibration curve, with a great deviation from experimental data. Consequently, method $\mathrm{A}$ is superior to method $\mathrm{B}$ in the analysis of $\mathrm{PGI}_{2}$ Na-salt samples. By the statistical treatment of the deviation of experimental points we found that it cannot be subjected to normal distribution. In addition we found that between the experimental points $1-5$ and $9-11$ (Fig. $3, b$ ) (these points correspond to different 6-keto-PGF ${ }_{1 \alpha}$ batches) a systematic error occurs. This suggests a 

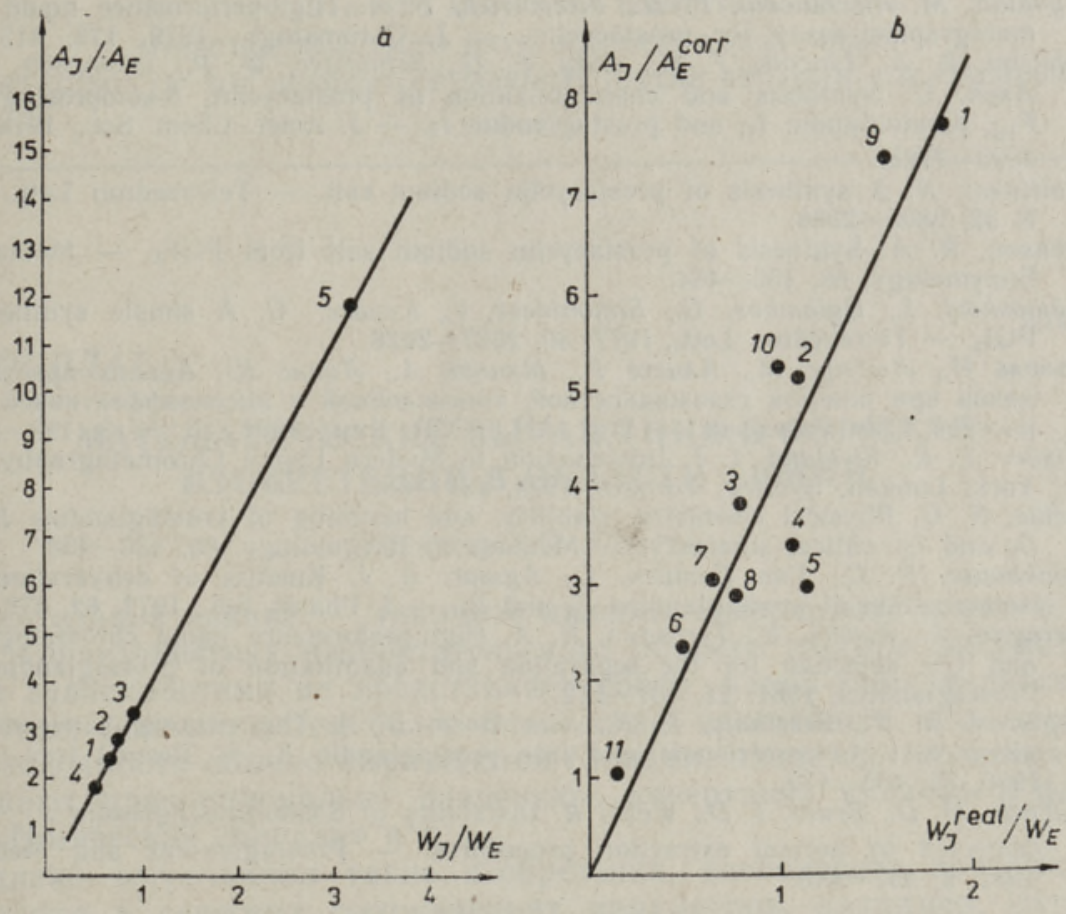

Fig. 3. Calibration curves of $\mathrm{PGI}_{2}$ Na-salt. $a-\operatorname{method~A,~} b-$ method B.

conclusion that the purity of 6-keto-PGF $1 \alpha$ in different batches is different due to difficulties in the preparation, extraction and purification of this compound $\left[{ }^{8,17}\right]$. The conditions under which 6-keto-PGF $\mathrm{PG}_{1 \alpha}$ can be used for constructing a calibration curve require further study.

\section{Conclusions}

1. The internal standard method using $\mathrm{PGE}_{1}$ as an internal standard for determining the purity of $\mathrm{PGI}_{2} \mathrm{Na}$-salt was developed.

2. The direct calibration method where a solution of pure $\mathrm{PGI}_{2} \mathrm{Na}$-salt was used (method A) is superior to the method via 6-keto-PGF $1 \alpha$ (method B).

3. $\mathrm{PGI}_{2} \mathrm{Na}$-salt response factor to $\mathrm{PGE}_{1}$ at $205 \mathrm{~nm}$ is 3.65 with a standard deviation of 0.05 . It provides sufficient precision for determining the purity of $\mathrm{PGI}_{2} \mathrm{Na}$-salt.

\section{RE FE RENCES}

1. Moncada, S., Gryglewski, R., Bunting, S., Vane, J. R. An enzyme isolated from arteries transforms prostaglandin endoperoxides to an unstable substance that inhibits platelet aggregations. - Nature (London), 1976, 263, 663-665.

2. Vane, J. R. Bioassay-Abenteuer auf dem Weg zum Prostacyclin (Nobel-Vortrag). Angew. Chem., 1983, 95, 782-794.

3. Pace-Asciak, C. Isolation, structure and biosynthesis of 6-ketoprostaglandin $F_{1 \alpha}$ in the rat stomach. - J. Amer. Chem. Soc., 1976, 98, 2348-2349.

4. Chiang, Y., Kresge, A. J., Cho, M. J. Acid catalyzed hydrolysis of prostacyclin: origin of the unused lability. - J. Chem. Soc. Chem. Communs, 1979, N 2, $129-130$.

5. Hill, G. T. High-performance liquid chromatographic determination of prostacyclin. - J. Chromatogr., 1979, 176, 407-412. 
6. Wynalda, M. A., Lincoln, F. H., Fitzpatrick, F. A. High-performance liquid chromatographic assay for prostacyclin. - J. Chromatogr., 1979, 176, 413-417.

7. Johnson, R. A., Lincoln, F. H., Nidy, E. G., Schneider, W. P., Thompson, J. L., Axen, $U$. Synthesis and characterization of prostacyclin, 6-ketoprostaglandin $F_{1 \alpha}$, prostaglandin $I_{1}$, and prostaglandin $I_{3}$. - J. Amer. Chem. Soc., 1978, 100, $7690-7705$.

8. Whittaker, N. A synthesis of prostacyclin sodium salt. - Tetrahedron Lett., 1977, N $32,2805-2808$.

9. Johnson, R. A. Synthesis of prostacyclin sodium salt from $\mathrm{PGF}_{2}$. - Methods in Enzymology, 86, 459-464.

10. Tömöskëzi, I., Galambos, G., Simonidesz, V., Kovàcs, G. A simple synthesis of $\mathrm{PGI}_{2 .}$. - Tetrahedron Lett., $1977,30,2627-2628$.

11. Самель Н.; Лыхмус М., Алисте Р., Мянник А., Лилле Ю. Анализ простагландинов при помощи газожидкостной, тонкослойной и высокоэффективной жидкостной хроматографии. - Изв. АН ЭССР. Хим., 1981, 30, № 3, 199-207.

12. Snyder, L. R., Kirkland, J. J. Introduction to Modern Liquid Chromatography. New York; London; Sydney; Toronto; 1974, 431-444.

13. Stehle, R. G. Physical chemistry, stability, and handling of prostaglandins $E_{2}, F_{2}$, $D_{2}$ and $I_{2}$ : critical summary. - Methods in Enzymology, 86, 436-458.

14. Monkhouse, D. C., Van Campen, L., Aguiar, A. J." Kinetics of dehydration and isomerization of prostaglandins $E_{1}$ and $E_{2}$. - J. Pharm. Sci., 1973, 62, 576-580.

15. Terragno, A., Rydzik, R., Terragno, N. A. High-performance liquid chromatography and UV detection for the separation and quantitation of prostaglandins. Prostaglandins, 1981, 21, 101-112.

16. Nugteren, D. H., Beerthuis, R. K., Van Dorp, D. A. The enzymic conversion of all-cis 8,11,14-eicosatrienoic acid into prostaglandin $E_{1}$. - Recueil trav. chim., $1966,85,405-419$.

17. Mitchell, M. D., Brunt, J. D., Webb, R. Instability of 6-keto-prostaglandin $F_{1 \alpha}$ when subjected to normal extraction procedures. - Prostaglandins and Medicine, $1981,6,437-440$.

Academy of Sciences of the Estonian SSR, Institute of Chemistry

Received Feb. 29, 1984

M. LOHMUS, Piret NIIDAS, M. LOPP, O. LILLE

\title{
PROSTATSUKLIINI KVANTITATIIVNE ANALUUS KÖRGFEKTIIVSEL VEDELIKUKROMATOGRAAFIAMEETODIL
}

On välja töötatud prostatsükliini määramise kvantitatiivne meetod, kasutades sisestandardit. On võrreldud kahte meetodit: A - sisestandardiks oli PGE $_{1}$; B - sisestandarditeks olid 6-keto- $\mathrm{PGF}_{1 \alpha}$ ja $\mathrm{PGE}_{1}$.

Meetod A andis piisava täpsusega tulemused. $205 \mathrm{~nm}$ juures oli $\mathrm{PGI}_{2}$ detekteerimise tundlikkus $3,65 \pm 0,15$ korda suurem kui $\mathrm{PGE}_{1}-1$.

\author{
М. ЛЫХМУС, Пирет НИИДАС, М. ЛОПП, Ю. ЛИЛЛЕ
}

\section{КОЛИЧЕСТВЕННЫИ АНАЛИЗ ПРОСТАЦИКЛИНА С ПОМОЩЬЮ МЕТОДА ВЫСОКОЭФФЕКТИВНОИ ЖИДКОСТНОИ ХРОМАТОГРАФИИ}

Разработан количественный метод определения чистоты натриевой соли простациклина с использованием внутреннего стандарта, в качестве которого служили ПГЕ (метод А) и 6-кето-ПГҒ ${ }_{1 \alpha}$, ПГЕ 1 (метод Б). Метод А дал результаты удовлетворительной точности. При 205 нм чувствительность детектирования натриевой соли ПГІ 2 превышала чувствительность детектирования ПГЕ 1 в $3,65 \pm 0,15$ раза. 